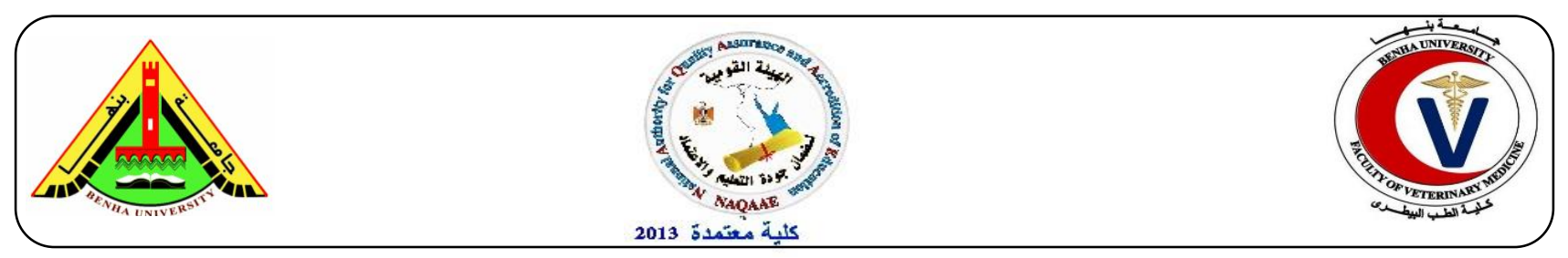

\title{
Potential protective effects of Quercetin on metalaxyl-induced oxidative stress, impaired liver functions and hepatotoxicity in rat
}

\author{
Samy A. Hussein ${ }^{1}$; Yakout A. El Senosi ${ }^{1}$; Mogda K. Mansour ${ }^{2}$ and Marwa F. Hassan ${ }^{2}$ \\ ${ }^{1}$ Department of Biochemistry, Faculty of Vet. Med., Benha University, Egypt. \\ ${ }^{2}$ Departments of Biochemistry and food deficiency, Animal Health Research Institute, Dokki-Giza; \\ Egypt.
}

*Corresponding author: Samy Ali Hussein; email: samyaziza@yahoo.com

\begin{abstract}
A B S T R A C T
The purpose of this study was to investigate the protective and anti-inflammatory influence of quercetin against metalaxyl fungicide induced liver toxicity and oxidative stress in rats. Forty two male albino rats were divided into three equal groups. Group I (normal group): rats administered distilled water. Group II (metalaxyl exposed group): rats received metalaxyl 1/10 LD $\mathrm{L}_{50}(130 \mathrm{mg} / \mathrm{kg}$ b.wt) orally three times per weeks for 8 weeks. Group III (metalaxyl + quercetin treated group): rats received metalaxyl $(130 \mathrm{mg} / \mathrm{kg}$ b.wt $)$ and treated with quercetin $(15 \mathrm{mg} / \mathrm{kg} \mathrm{b.wt/day/i.p})$. The obtained results showed significant increase in serum liver marker enzymes (ALT, AST and ALP) activities, liver tissue L-MDA and inflammatory markers (MPO and IL-6) levels in metalaxyl exposed rats. However, activities of liver tissue antioxidant enzymes (SOD, CAT) and GSH levels were markedly decreased. Administration of quercetin with metalaxyl exposed rats caused significant improvement of all previous parameters towards its normal ranges. These results suggested that, quercetin treatment may have a protective effect against metalaxyl fungicide induced liver damage and oxidative stress in rats via anti-inflammatory activity and free radical scavenging as well as regenerating endogenous antioxidant defense system mechanisms.
\end{abstract}

Key words: Metalaxyl, quercetin, antioxidant, inflammatory markers

(http://www.bvmj.bu.edu.eg)

(BVMJ-33(2): 517-532, 2017)

\section{INTRODUCTION}

Pesticides are used extensively throughout the world to control agricultural pests and protect public health. Although these chemicals have many beneficial purposes, they can also cause adverse effects in both humans and animals. Pesticides have chronic health effects both as the sequlae of acute poisonings and through chronic exposure. There is also convincing evidence that pesticides play a role in human cancers. For example, epidemiological studies have linked insecticide exposure in the home to the development of leukemia in children and brain cancer. Many of these compounds are environmentally persistent and may not be entirely specific for their target organisms, endangering other living species, including animals and humans (Aprea et al., 2002; 
Ding et al., 2012). Several pesticides exert their biological influence mainly via electrophilic attack of cellular constituents with simultaneous production of reactive oxygen species (ROS) (Al-Attar, 2015). ROS is a main cellular source of oxidative stress and ultimately results in widespread oxidation of biomolecules includes proteins, lipids and nucleic acid (Elzoghby et al., 2014).

Metlaxyl is used to control soil-borne diseases caused by Phytophthora and Pythium on fruits, cotton, soyabean, peanuts, ornamentals and grasses (Sukul and Spiteller, 2000). The problems resulting from metalaxyl come from their high residual level in agriculture crops especially vegetables cultivated under greenhouse conditions and other components of environment (Pattanasupong et al., 2004). Also, metalaxyl is soluble in water and has the potential to reach groundwater and stable under when exposed to sunlight, with a halflife 57 weeks (United States Environmental Protection Agency 1994). Metalaxyl exposure leads to abnormal haematological and biochemical activities induce oxidative stress and an observable toxicity (AlAmoudi, 2012).

To control the level of ROS and to protect cells under stress conditions, mammalian tissues contain several enzymatic superoxide dismutase (SOD) and catalase (CAT), and reduced glutathione (GSH) that scavenge ROS. Because of continuous exposure of pesticides, the level of these endogenous antioxidants decreases leading to accelerated cell damage (Ojo et al., 2014). Flavonoids are phenolic phytochemicals that influences in protecting cellular components against ROS (Hertog et al., 1996). Their antiradical property is directed towards highly reactive species implicated in the initiation of lipid peroxidation. Furthermore, flavonoids are soluble chain-breaking inhibitors of the peroxidation process, scavenging alkoxyl radicals and intermediate peroxyl (Jovanovic et al., 1998). Quercetin, 3,5,7,3',4'pentahydroxyflavone, is a polyphenolic flavonol molecule that occurs in many fruits and vegetables such as onions, apples, soybeans, potatoes, berries, peanuts, grapes, tea, citrus fruits and broccoli (Anjaneyulu and Chopra, 2003; Bouhali et al., 2015). Daily intake of quercetin is estimated up to $25 \mathrm{mg} /$ day in a normal human diet (Dajas et al., 2003). The antioxidant capacity of these molecules seems to be responsible for several beneficial effects and gives a therapeutic potential in diseases such as hepatic pathologies, cardiovascular diseases, gastric or duodenal ulcers and cancer (Gonzalez-Gallego et al., 2007). Additionally, Quercetin is a stronger antioxidant than the other antioxidant nutrients such as vitamin $\mathrm{E}, \mathrm{C}$ and b-carotene etc. (Rice-Evans et al., 1995). This study was to investigate the possible protective effect of quercetin against deleterious effect of metalaxyl intoxication in adult male rats through investigation of liver functions, inflammatory markers, oxidative stress biomarkers and enzymatic antioxidant status.

\section{Materials and methods}

\subsection{Experimental animals:}

Forty-two white male albino rats of 45 weeks old and weighing $150-200 \mathrm{~g}$ were used in this study. Rats were housed in separated metal cages and kept at constant environmental and nutritional conditions throughout the period of experiment. The rats were fed on constant ration and fresh, clean drinking water was supplied ad-libitum. All rats were acclimatized for minimum period of two weeks prior to the beginning of study.

\subsection{Chemicals and antioxidant:}


All chemicals were of analytical grade and obtained from standard commercial suppliers .The antioxidant and chemicals used in the present study were:

a- Metalaxyl: Metalaxyl $\quad[N-(2,6-$ Dimethylphenyl)- $N$-(methoxyacetyl)-DLalanine methyl ester], $98 \%$ technical grade was obtaied from Zhejiang Heben Pesticide \& Chemicals Co., Ltd. China. freshly prepared and administered orally three times per weeks at a dose of $130 \mathrm{mg} / \mathrm{kg}$ b.wt (1/10 of $\mathrm{LD}_{50}$ ) (Sakr and Lamfon, 2005).

b- Quercetin: quercetin was purchased from Aktin Chemicals, Inc. company (Nature connecting health), Chengdu, China., it administered intraperitoneal to rats at a dose level (15 mg / kg b.wt/ i.p.) once daily for 8 weeks (Khaki et al., 2009).

Quercetin stock solution preparation:

Quercetin (100 mg) was mixed in 0.5 $\mathrm{ml}$ dimethyl sulfoxide (DMSO) and $1 \mathrm{ml}$ Tween 80 was added then diluted with normal saline to make $7 \mathrm{ml}$ injectable fine suspension and administered intraperetinoel in a volume of $0.5 \mathrm{ml}$ per rat (Indap et al., 2006).

c- Other chemicals used in this study were of the highest purified grades available purchased from El Gomhouria Company for Trading Chemicals and Medical Appliances, Egypt.

\subsection{Experimental design:}

After acclimatization to the laboratory conditions, the animals were randomly divided into three groups (14 rats each) placed in individual cages and classified as follow:

Group I (normal control group): Rats received no drugs, served as control nontreated for all experimental groups.

Group II (metalaxyl exposed group): Rats received metalaxyl at a dose level of $1 / 10$ $\mathrm{LD}_{50}(130 \mathrm{mg} / \mathrm{kg}$ b.wt $)$ orally three times per weeks for 8 weeks.

Group III (metalaxyl + quercetin treated group): Rats received metalaxyl $(130 \mathrm{mg} / \mathrm{kg}$ b.wt) orally three times per weeks and treated daily with quercetin $(15 \mathrm{mg} / \mathrm{kg}$ b.wt/ i.p) for 8 weeks.

\subsection{Sampling:}

\subsubsection{Blood samples:}

About $5 \mathrm{ml}$ of blood samples were collected by ocular vein puncture from all animal groups two times along the duration of experiment at 4 and 8 weeks in dry, clean tubes and allowed to clot for 30 minutes and serum was separated by centrifugation at 3000 r.p.m for 15 minute. The serum was taken by automatic pippte and received in dry sterile tubes, then kept in deep freeze at $20{ }^{\circ} \mathrm{C}$ until use for subsequent biochemical analysis. All sera were analyzed for determination of the following parameters: AST, ALT and ALP.

\subsubsection{Tissue samples:}

About $0.5 \mathrm{gm}$ of liver tissue specimen was taken two times from each groups of rats after had been sacrificed at 4 and 8 weeks from the onset of rats exposed to metalaxyl. The specimens were immediately removed and washed several times with saline and blotted between two damp filter papers, weighed and stored at $-20^{\circ} \mathrm{C}$ for subsequent biochemical analyses.

\subsubsection{Liver tissue for biochemical analysis}

Briefly, liver tissues were cut, weighed and minced into small pieces, homogenized with a glass homogenizer in 9 volume of icecold $0.05 \mathrm{mM}$ potassium phosphate buffer (pH 7.4) to make $10 \%$ homogenates. The homogenates were centrifuged at 6000 r.p.m for 15 minutes at $4{ }^{\circ} \mathrm{C}$ then the resultant 
supernatant was used for the determination of the following parameters: L-MDA, MPO, SOD, CAT.

$0.2 \mathrm{gm}$ of liver tissues were minced into small pieces homogenized with a glass homogenizer in $0.4 \mathrm{ml}$ of $25 \%$ metaphosphoric acid (MPA) (ref. No.: 253433-4, Sigma-Aldrich, Germany), then 1.4 $\mathrm{ml}$ of distilled water was added, mixed and incubated for 1 hour and centrifuged for 10 min at 3,000 r.p.m then the clean supernatant was removed and used for determination of GSH levels.

2.4.2.2. Liver tissue for molecular gene expression

About $0.5 \mathrm{gm}$ of liver tissue put in eppendorf tubes and were immediately kept in liquid nitrogen and stored at $-80^{\circ} \mathrm{C}$ till RNA extraction for determination of IL- 6 level.

\subsection{Biochemical analysis}

Serum ALT, AST were determined according to the method described by Schumann et al., (2002) and serum ALP activity was determined enzymatically according to EL-Aaser and EL-Merzabani, (1975). Liver tissue L-MDA, MPO, SOD, CAT and GSH were determined according to the method described by Mesbah et al., (2004), Bradley et al., (1982), Kakkar et al., (1984), Xu et al., (1997) and Patterson and Lazarow, (1955) respectively. Moreover, the mRNAexpression level of IL-6 was determined by real-time quantitative polymerase chain reaction (real- time qPCR) analysis in liver of rats. Target gene was normalized with $\beta$-actin by used the $2^{-\Delta \Delta \mathrm{Ct}}$ method (Livak and Schmittgen, 2001).

\subsection{Statistical analysis:}

The results were expressed as mean \pm SE using SPSS (13.0 software, 2009) program. The data were analyzed using oneway ANOVA to determine the statistical significance of differences among groups. Duncan's test was used for making a multiple comparisons among the groups for testing the inter-grouping homogeneity. Values were considered statistically significant when $\mathrm{p}<0.05$.

\section{RESULTS}

The obtained data presented in table (1) revealed that, metalaxyl intoxicated rats showed significant increase in serum ALT, AST and ALP activities all over the periods of the experiment when compared to normal control group.

Quercetin treatment to metalaxyl intoxicated male rats caused a significant decrease in elevated serum ALT and AST activities all the period of experiment, while a non-significantly increase in ALP activity after 4 weeks followed by a significantly decrease after 8 weeks of experimental when compared with metalaxyl exposed group.

The obtained data presented in table (2) revealed that, metalaxyl intoxicated rats showed significant increase in liver tissue LMDA, MPO levels and significant upregulation of IL- 6 all over the periods of the experiment when compared to normal control group.

Quercetin treatment to metalaxyl intoxicated male rats caused a significant decrease in elevated liver tissue L-MDA, MPO levels and a significant downregulation IL-6 gene expression when compared with metalaxyl toxic group.

The obtained data presented in table (3) revealed, significant decrease in CAT activity in metalaxyl intoxicated rats after four weeks followed by a non-significant decrease after eight weeks of the experiment, associated with a significant decrease in SOD activity and GSH content all over the period of experiment compared to control. 
Quercetin treatment to metalaxyl intoxicated male rats caused a nonsignificant increase in CAT and SOD activities after four weeks
This increase became significant after eight weeks associated with a significant increase in liver tissue GSH concentration all over the periods of the experiment when compared with metalaxyl exposed group.

Table (1): Effect of quercetin administration on serum ALT, AST and ALP activities in metalaxyl intoxicated male rats $(\mathrm{U} / \mathrm{L})$.

\begin{tabular}{llll}
\hline Parameters & ALT $(\mathrm{U} / \mathrm{L})$ & AST(U/L) & ALP(U/L)
\end{tabular}

Exp. groups

4 weeks $\quad 8$ weeks $\quad 4$ weeks $\quad 8$ weeks $\quad 4$ weeks

Group I:

Normal control

$29.00 \pm 1.53^{\mathrm{d}} \quad 27.67 \pm 3.18^{\mathrm{d}} \quad 54.00 \pm 0.58^{\mathrm{e}} \quad 57.00 \pm 1.53^{\mathrm{d}}$

$138.33 \pm 3.84^{\mathrm{d}} \quad 178.67 \pm 6.98^{\mathrm{d}}$

Group П :

Metalaxyl group

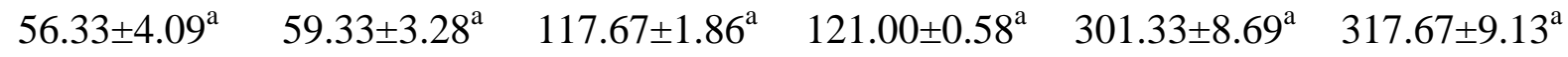

Group III:

Metalaxyl $+\quad 44.67 \pm 3.48^{\mathrm{b}} \quad 38.00 \pm 0.58^{\mathrm{bc}} \quad 83.33 \pm 1.76^{\mathrm{b}} \quad 79.00 \pm 1.53^{\mathrm{c}} \quad 305.67 \pm 2.96^{\mathrm{a}} \quad 265.67 \pm 10.04^{\mathrm{b}}$

Quercetin

Data are presented as (Mean \pm S.E). $\quad$ S.E $=$ Standard error.

Mean values with different superscript letters in the same column are significantly different at $(\mathrm{P} \leq 0.05)$.

Table (2): Effect of quercetin administration on liver tissue L-MDA, MPO and IL-6 levels in metalaxyl intoxicated male rats.

Parameters L-MDA (mmol/g tissue $) \quad$ MPO $(\mu / \mathrm{mg}$ protein $) \quad \begin{gathered}\text { Fold change in IL-6 gene } \\ \text { expression }\end{gathered}$

4 weeks $\quad 8$ weeks $\quad 4$ weeks $\quad 8$ weeks $\quad 4$ weeks 4 weeks

Exp. groups

Group I:

Normal control

$4.08 \pm 0.01^{\mathrm{d}}$

$4.46 \pm 0.05^{\mathrm{c}}$

$0.05 \pm 0.001^{\mathrm{d}}$

$0.08 \pm 0.002^{\mathrm{d}}$

$1.00 \pm 0.07^{\mathrm{d}}$

$1.00 \pm 0.08^{\mathrm{d}}$

Group П :

Metalaxyl group

$$
7.64 \pm 0.13^{\mathrm{a}}
$$

$8.37 \pm 0.07^{\mathrm{a}}$

$0.54 \pm 0.009^{\mathrm{a}}$

$0.69 \pm 0.010^{\mathrm{a}}$

$10.63 \pm 0.25^{\mathrm{a}}$

$15.45 \pm 0.36^{\mathrm{a}}$

Group III:

Metalaxyl +

$6.34 \pm 0.27^{b}$

$5.20 \pm 0.04^{\text {bc }}$

$0.38 \pm 0.008^{b} \quad 0.47 \pm 0.009^{b}$

$6.45 \pm 0.21^{\mathrm{b}}$

$10.85 \pm 0.27^{\mathrm{b}}$

Quercetin

Data are presented as (Mean \pm S.E). $\quad$ S.E $=$ Standard error.

Mean values with different superscript letters in the same column are significantly different at $(\mathrm{P} \leq 0.05)$. 
Table (3): Effect of quercetin administration on liver tissue SOD, CAT activities and GSH concentration in metalaxyl intoxicated male rats.

\begin{tabular}{|c|c|c|c|c|c|c|}
\hline \multirow{2}{*}{$\begin{array}{l}\text { Parameters } \\
\text { Exp. groups }\end{array}$} & \multicolumn{2}{|c|}{ SOD (u/g.tissue) } & \multicolumn{2}{|c|}{ CAT (mmol/g.tissue) } & \multicolumn{2}{|c|}{ GSH (ng/g.tissue) } \\
\hline & 4 weeks & 8 weeks & 4 weeks & 8 weeks & 4 weeks & 8 weeks \\
\hline $\begin{array}{l}\text { Group I: } \\
\text { Normal control }\end{array}$ & $44.37 \pm 2.19^{\mathrm{bc}}$ & $48.15 \pm 3.02^{b}$ & $1.14 \pm 0.02^{\mathrm{a}}$ & $1.17 \pm 0.03^{b c}$ & $4.40 \pm 0.18^{\mathrm{ab}}$ & $4.77 \pm 0.14^{\mathrm{a}}$ \\
\hline $\begin{array}{l}\text { Group } \Pi \text { : } \\
\text { Metalaxyl group }\end{array}$ & $31.14 \pm 2.55^{\mathrm{d}}$ & $37.56 \pm 2.03^{c}$ & $1.03 \pm 0.03^{\mathrm{b}}$ & $1.07 \pm 0.01^{\mathrm{c}}$ & $3.36 \pm 0.07^{\mathrm{c}}$ & $3.88 \pm 0.03^{b}$ \\
\hline Group III: & & & & & & \\
\hline $\begin{array}{l}\text { Metalaxyl + } \\
\text { Quercetin }\end{array}$ & $37.80 \pm 1.87^{\mathrm{cd}}$ & $57.50 \pm 0.95^{b}$ & $1.10 \pm 0.04^{b}$ & $1.46 \pm 0.08^{\mathrm{a}}$ & $4.15 \pm 0.08^{b}$ & $5.12 \pm 0.34^{\mathrm{a}}$ \\
\hline
\end{tabular}

Data are presented as (Mean \pm S.E). $\quad$ S.E $=$ Standard error.

Mean values with different superscript letters in the same column are significantly different at $(\mathrm{P} \leq 0.05)$.

\section{DISCUSSION}

Metalaxyl intoxicated rats showed a significant increase in serum ALT, AST and ALP activities all over the periods of the experiment when compared with normal control group. Similarly, Abolaji et al., (2017) demonstrated that, individual administration of insecticide chlorpyrifos or fungicide carbendazim and their co-treatment caused liver damage evidenced by the significant increase in plasma ALT and AST activities when compared with the normal rat. The levels of some important biochemical parameters in serum are used as diagnostic markers of hepatic damage. One of the most sensitive and dramatic indicators of hepatocyte damage is the release of intracellular enzymes, such as transaminases and ALP. The elevated activities of these enzymes are signal of cellular leakage and the loss of the functional integrity of the cell membranes in liver which are always associated with hepatonecrosis (Naik and Panda, 2008; Howell et al., 2014).
Elevated activities of AST and ALP were found to be related to damage in the liver and the change in hepatic functions (Kanbur et al., 2009). This elevation could potentially be attributed to the release of these enzymes from the cytoplasm into the blood circulation, indicating a necrosis and inflammatory reactions (Sidhu et al., 2014).

Quercetin treatment significantly decreases ALT, AST and ALP activities, suggest that quercetin has a protective effect in rats with metalaxyl-induced liver toxicity. Similarly, David et al., (2011) showed that, treatment with quercetin for four days in rats intoxicated with thioacetamide promoted significant reduction in serum AST and ALT activities with successful avoidance of morphological alterations. Moreover, the administration route and the duration of treatment may interfere with the hepatoprotective effect of quercetin. Treatment duration impacts the effect of quercetin, and 
that periods longer than one week may be more effective to produce observable results (Behling et al., 2004; Bona et al., 2012). Also, El-Shafey et al., (2015) reported that, administration of quercetin $(15 \mathrm{mg} / \mathrm{kg} /$ day $)$ for 21 days prior to a toxic dose of paracetamol cause significant decrease activities of AST, ALT, and ALP. The antioxidant effect of quercetin may be due to its higher diffusion into the membranes allowing it to scavenge oxyradicals at several sites via the lipid bilayer (Moridani et al., 2003). It also can be resulting from pentahydroxyflavone structure allowing it to chelate metal ions through the orthodihydroxy phenolic structure thereby scavenging peroxyl radical and lipid alkoxyl (Cao et al., 1997).

Presented findings showed that, treatment with metalaxyl in rats exhibited a significant increase in liver tissue L-MDA, MPO and significant up-regulation of IL-6 when compared with normal group control. These results were nearly similar to those recorded by Ahmed and Nasr, (2015) who found that, administration of imidacloprid insecticide caused significantly increased in brain tissue MPO activity when compared with normal rat. ROS are constantly generated during the metabolic processes of all living species (Sakr and Abel-Samie, 2008). Under normal physiological conditions, cellular ROS generation is counterbalanced by the action of antioxidant enzymes and other redox molecules. Oxidative stress is potentially harmful to tissues, and ROS are produced as a reaction to pesticide toxicity, including fungicide exposure. In this regard, Sakr, (2007) suggested that, metalaxyl induced a significant increase in oxidative stress and malondialdehyde caused a significant decrease in the level of serum antioxidant enzymes, namely, superoxide dismutase and catalase in mice. Oxidative damage primarily occurs through production of ROS including hydroxyl radicals and hydrogen peroxide that are generated during the reaction and react with biological molecules, eventually damaging membranes and other cells (Heikal et al., 2014). Lipid peroxidation has used as biomarkers of pesticides induced oxidative stress and suggested as one of the molecular mechanisms involved in pesticides-induced toxicity (Mossa et al., 2015).

The observed increase of liver tissue MPO activity leads to stimulation of proinflammatory cytokine expression. MPO activates neutrophils and promotes their recruitment leading to an enhanced proinflammatory immune response (Klinke et al., 2011), suggests that, as with other pesticides, metalaxyl may mediate its effect through the NF-kB pathway in the chronic phase of inflammation. NF-kB mediates the cellular responses to a wide variety of extracellular stress stimuli (Jung et al., 2014), and upregulates the expression of cytokines, such as TNF- $\alpha$, IL-6 and inducible nitric oxide synthase (iNOS) to initiate inflammatory responses and apoptosis (Nakamoto and Kanai, 2014). As well as activate them to produce oxidants including superoxide derived nicotinamide adenine dinucleotide phosphateoxidase (NADPH) and endocytose bacteria carried through the portal circulation (Moore et al., 2013). NADPH may stimulate, in hepatocytes, the production of ROS (Bhogal et al., 2010) that cause DNA damage, induce apoptosis, the expression of genes involved in the synthesis of pro-inflammatory cytokines. INOS may stimulate hepatocyte toxicity by increasing the production of nitric oxide (Czaja, 2014). The results from the abovementioned authors indicated that metalaxyl induced oxidative stress and inflammation in rats, which in turn led to observable toxicity.

Treatment with quercetin in metalaxyl intoxicated rats significantly reduced elevated 
liver tissue L-MDA, MPO and IL-6 level when compared with metalaxyl intoxicated rats these results came in accordance with the recorded data of, Bahar et al., (2017) who reported that, quercetin treatment to rats significantly down regulate NF-kB, TNF- $\alpha$ and IL-6 protein expression when compared to $\mathrm{Mn}$-treated groups. Quercetin may reduce the generation of ROS by activated leukocytes and also may reduce the release of interferon-c from leukocytes. Interferon-c is partially responsible for inhibition of ROS production (Chirumbolo, 2010).

Quercetin treatment lead to a significantly decrease in liver MPO activity. Similarly, Tinay et al., (2017) suggested that, quercetin inhibited lipid peroxidation and prevented MPO activity, suggesting protection against ischemia/reperfusion induced oxidative damage in rats. One probably mechanism of action for quercetin is the suppression of neutrophil recruitment into the site of injury and subsequent decrease in MPO released into the injured tissue (Schultke et al., 2010). Quercetin antioxidant efficacy may be attributed to a high diffusion rate into membranes, allowing it to scavenge free radicals (Moridani et al., 2003). In the present study, quercetin significantly decreased gene expression of IL-6. Similarly, Alahmari et al., (2017) reported that, quercetin was effective for inhibiting the elevation of IL- $1 \beta$ and IL-6, induced by arsenic toxicity. Quercetin inhibits inflammation through the down-regulation of the NF-kB pathway and lipopolysaccharide (LPS) induced production as well as the gene regulation of cytokines (Comalada et al., 2005).

The obtained results demonstrated that, a significant decrease in liver tissue CAT and SOD and GSH in metalaxyl treated rats. These results were nearly similar to those reported by Abolaji et al., (2017) who reported that, exposure to insecticide chlorpyrifos alone, fungicide carbendazim alone and their cotreatment resulted in significant decrease in SOD, CAT and GSH level in the liver, kidney, and spleen when compared with the control rat. Under oxidative stress, GSH is depleted by GSH related enzymes to detoxify the peroxides produced due to increased lipid peroxidation (Cathcart, 1985). Decreased serum glutathione level has been observed due to metalaxyl oral treatment in rats (Hashem, 2012). SOD is enzyme that catalyzes the dismutation of superoxide radicals into oxygen and hydrogen peroxide. Thus, they constitute the first line of defense against ROS (Almeida et al., 2005). Sakr and Abel-Samie, (2008) found that, mancozeb fungicides induce a significant decrease SOD in serum. the decrease in SOD activity might be due to the suppression of SOD synthesis due to a genetic defect, leak of SOD out of cell due to increase in the production of oxygen radical causing cell membrane damage and inactivation of SOD by increased peroxide level in cell (Suzuki et al., 1991).

The obtained results showed that, treatment with quercetin in metalaxyl intoxicated rats significantly increased the reduced liver tissue CAT, SOD and GSH levels. Similarly, Bahar et al., (2017) reported that, quercetin treatment to rats effectively decreased ROS and increased $\mathrm{Cu} / \mathrm{Zn}-\mathrm{SOD}$ activity when compared to Mn-treated groups. Flavonoids and quercetin in particular, are potent antioxidants and known to modify the activities of different enzymes because of their interactions with several biomolecules. The cyto-protective effect of quercetin may also be due to its ability to interact with and penetrate the lipid bilayer (Behling et al., 2004). Quercetin treatment activated the Nrf2 transcription factor in cell line (Bahar et al., 2017). Nrf2 is a critical transcription factor regulating the anti-oxidant genes such as GSH, SOD and CAT by binding to antioxidant response elements (Barcelos et al., 
2016). It has been recorded that the upregulation of these enzymes due to Nrf2 transcription plays an important role in response to oxidative stress and contributes to the cytoprotective adaptive response (Zoja et al., 2014). Quercetin may exert its protective effect against metalaxyl-induced hepatic toxicity in rats possibly through its antioxidant and anti-inflammatory mechanisms.

\section{CONCLUSION}

The present study demonstrated that, administration of quercetin ameliorate actions and deleterious effects caused by exposure to toxic metalaxyl fungicide. Pesticide toxicity affected different organs mainly liver and these occurred through affected in several parameters. Metalaxyl caused significant increase in serum AST, ALT, ALP and liver tissue L- MDA, MPO and IL-6, however, a significant reduce in liver tissue SOD, CAT and GSH. Quercetin treatment in metalaxyl intoxicated rats ameliorated all previous parameters towards its normal range with best result after 8 weeks. So, these results confirm the highly antioxidant, anti-inflammatory and hepato-protective effects of quercetin in metalaxyl toxicity.

\section{REFERENCES}

Abolaji, A.O., Awogbindin, I.O., Adedara, I.A., Farombi, E.O. 2017. Insecticide chlorpyrifos and fungicide carbendazim, common food contaminants mixture, induce hepatic, renal, and splenic oxidative damage in female rats. Human and Experimental Toxicology 36(5), 483-493.

Ahmed, M.M.; Nasr, S.A. 2015. Protective effect of broccoli and ferulic acid on imidacloprid-induced neurotoxicity in rats. Journal of Biomedical and Pharmaceutical Research 4 (4), 8289.
Alahmari, A.S., Adham, k.G.E., Alhimaidi, A.R. 2017. Immunotoxic and genotoxic effects of arsenic and ameliorative potential of quercetin and probiotics in wistar rat. American Journal of Life Sciences 5(4), 108115.

Al-Amoudi, W.M. 2012. Haematological and biochemical effects of metalaxyl fungicide on albino mice. American Journal of Biochemistry 2(5), 62-66.

Al-Attar, A.M. 2015. Effect of grapeseed oil on diazinon-induced physiological and histopathological alterations in rats. Saudi J Biol Sci 22, 284-292.

Almeida, J.M., Fidalgo, F., Confraria, A., Santos, A., Pires, H., Santos, I. 2005. Effect of hydrogen peroxide on catalase gene expression, isoform activities and levels in leaves of potato sprayed with homobrassinolide and ultrastructural changes in mesophyll cells, Funct. Plant Biol 32, 707-720.

Anjaneyulu, M.K., Chopra, J.K. 2003. Antidepressant activity of Quercetin, a bioflavonoid, in streptozotocininduced diabetic mice. Journal of medical food Winter, 6(4): 391-395.

Aprea, C., Colosio, C., Mammone, T., Minoia, C., Maroni, M. 2002. Biological monitoring of pesticide exposure: a review of analytical methods. J. Chromatogr. B Analyt. Technol. Biomed. Life Sci 769, 191219.

Bahar, E., Ji-Ye Kim, J.Y., Yoon, H. 2017. Quercetin Attenuates ManganeseInduced Neuroinflammation by Alleviating Oxidative Stress through Regulation of Apoptosis, iNOS/NF$\mathrm{kB}$ and HO-1/Nrf2 Pathways. 
International Journal of Molecular Sciences 18(1989), 1-19.

Barcelos, R.P., Bresciani, G., RodriguezMiguelez, P., Cuevas, M.J., Soares, F.A., Barbosa, N.V., GonzalezGallego, J. 2016. Diclofenac pretreatment effects on the toll-like receptor 4/nuclear factor-kB-mediated inflammatory response to eccentric exercise in rat liver. Life Sci 148, 247-253.

Behling, E.B., Sendão, M.C., Francescato, H.D.C., Antunes, L.M.G., Bianch, M.L.P. 2004. Flavonóide quercetina: aspectos gerais e ações biológicas. Alim Nutr Araraquara 15(3), 285-292.

Bhogal, R.H., Curbishley, S.M., Weston, C.J., Adams, D.H., Afford, S.C. 2010. Reactive oxygen species mediate human hepatocyte injury during hypoxia/reoxygenation. Liver Transpl 16, 1303-1313.

Bona, S., Filippin, L.I., DI Naso, F.C., David, C., Valiatti, B., Schaun, M.I., Xavier, R.M., Marroni, N.P. 2012. Effect of Antioxidant Treatment on Fibrogenesis in Rats with Carbon Tetrachloride-Induced Cirrhosis. ISRN Gastroenterol 2012, 1-12.

Bouhali, I.E., Tayaa, B., Tahraoui, A. 2015. Quercetin, a natural flavonoid, mitigates fenthion induced locomotor impairments and brain acetylcholinesterase inhibition in male wistar rat, Middle-East Journal of Scientific Research 23(1), 55-58.

Bradley, P.P., Priebat, D.A., Christensen, R.D., Rothstein, G. 1982. Measurement of cutaneous inflammation: Estimation of neutrophil content with an enzyme marker. J. Invest. Dermatol 78, 206209.
Cao, G., Sofic, E., Prior, R.L. 1997. Antioxidant and prooxidant behavior of flavonoids: structure-activity relationships. Free Radic. Biol. Med 22, 749-760.

Cathcart, R.F. 1985. Vitamin C: the nontoxic, non rate-limited, antioxidant free radical scavenger. Medical Hypothesis $18,61-77$.

Chirumbolo, S. 2010. The role of quercetin, fl avonols and $\mathrm{fl}$ avones in modulating infl ammatory cell function . Inflam. Aller. Drug Targ. 9, 263 - 285.

Comalada M., Camuesco D., Sierra S., Ballester I., Xaus J., Galvez J., Zarzuelo A. 2005. 'In vivo quercitrin anti-inflammatory effect involves release of quercetin, which inhibits inflammation through downregulation of the NF-kappaB pathway', Eur. J. Immunol 35(2), 584592.

Czaja, A.J. 2014. Hepatic inflammation and progressive liver fibrosis in chronic liver disease. World J. Gastroenterol 20, 2515-2532.

Dajas, F., Rivera-Megret, F., Blasina, F., Arredondo, F., Abin-Carriquiry, J.A, Costa, G., Echeverry, C., Lafon L., Heizen, H., Ferreira, M., Morquio, A. 2003. Neuroprotection by flavonoids. (Review). Brazilian journal of medical and biological research 36(12), 16131620.

David, C., Rodrigues, G., Bona, S., Meurer, L., González-Gallego, J., Tuñón, M.J., Marroni, N.P. 2011. Role of Quercetin in Preventing Thioacetamide-Induced Liver Injury in Rats. Toxicol Pathol, 39(6), 949-957.

Ding, F., Li, X.N., Diao, J.X., Sun, Y., Zhang, L., Sun, Y. 2012. Chiral recognition of metalaxyl enantiomers by human 
serum albumin: evidence from molecular modeling and photophysical approach" Chirality. 24(6), 471-480.

EL-Aaser, A.A., EL-Merzabani, M.M. 1975. Simultaneous determination of 5'nucleotidase and alkaline activities in serum. Z. Klin. Chem. Klin.Biochem 13, 453 .

El-Shafey, M.M., Abd-Allah, G.M., Mohamadin, A.M., Harisa, G.I., Mariee, A.D. 2015. Quercetin protects against acetaminophen-induced hepatorenal toxicity byreducing reactive oxygen and nitrogen species. Pathophysiol, 22, 49-55.

Elzoghby, R.R., Hamuoda, A.F., AbdelFatah, A., Farouk, M. 2014. Protective role of vitamin $\mathrm{c}$ and green tea extract on malathion-induced hepatotoxicity and nephrotoxicity in rats. Am J Pharmacol Toxicol 9, 177-188.

Gonzalez-Gallego, J., Sanchez-Campos, S., Tunon, M.J. 2007. Anti-inflammatory properties of dietary flavonoids. Nutr. Hosp 22, 287-293.

Hashem, H.E. 2012. Light and electron microscopic study of the possible protective effect of nigella sativa on metalaxyl induced hepatotoxicity in adult albino rats. Cell Science and Therapy 3(2), 1-6.

Heikal, T.M., Mossa, A.T.H., Ibrahim, A.W., Abdel-Hamid, H.F. 2014. Oxidative damage and reproductive toxicity associated with cyromazine and chlorpyrifos in male rats: the protective effects of green tea. Res $\mathrm{J}$ Environ Toxicol 8, 53-67.

Hertog, M.G.L., Hollman, P.C.H., 1996. Potential health effects of the dietary flavonol quercetin. Eur J Clin Nutr 50, 63-71.

Howell, B.A., Siler, S.Q., Shoda, L.K.M., Yang, Y., Woodhead, J.L., Watkins, P.B. 2014. A mechanistic model of drug-induced liver injury AIDS the interpretation of elevated liver transaminase levels in a phase I clinical trial. CPT Pharmacometrics Syst Pharmacol 3(e98), 1-8.

Indap, M.A., Bhosle, S.C., Shinde, A.D., Barkume, M.S., Ingle, A.D. 2006. Tumour response to quercetin, a bioflavonoid with some promises in therapies. Indian J Pharm Sci 68, 570574.

Jovanovic, S.V., Steenken, S., Simic, M.G., Hara, Y. 1998. Antioxidant properties of flavonoids: reduction potentials and electron transfer reactions of flavonoid radicals. In Flavonoids in Health and Disease. C Rice Evans, L Packer (eds). NewYork; Marcel Dekker 137161.

Jung, H.S., Joo, J.D., Kim, D.W., In, J.H., Roh, M., Jeong, J.T., Noh, S.J., Choi, J.W. 2014. Effect of milrinone on the inflammatory response and NF-kB activation in renal ischemiareperfusion injury in mice. Korean $\mathrm{J}$. Anesthesiol 66, 136-142.

Kakkar, P., Das, B., Viswanathan, P.N. 1984. A modified spectrophotometric assay of superoxide dismutase. Indian $\mathbf{J}$. Biochem Biophys 21, 130-132.

Kanbur, M., Eraslan, G., Silici, S., Karabacak, M. 2009. Effects of sodium fluoride exposure on some biochemical parameters in mice: Evaluation of the ameliorative effect of royal jelly applications on these parameters. Food Chem. Toxicol 47, 1184-1189. 
Khaki, A.A., Khaki, A., Nouri, M., AhmadiAshtiani, H.R., Rastegar, H., Rezazadeh, Sh., Fathiazad, F., Ghanbari, M. 2009. Evaluation Effects of Quercetin on Liver Apoptosis in Streptozotocin-induced Diabetic Rat. Journal of Medicinal Plants 8 (5),70 78.

Klinke, A., Nussbaum, C., Kubala, L., Friedrichs, K., Rudolph, T.K., Rudolph, V., Paust, H.J., Schroder, C., Benten, D., Lau, D., Szocs, K., Furtmuller, P.G., Heeringa, P., Sydow, K., Duchstein, H.J., Ehmke, H., Schumacher, U., Meinertz, T., Sperandio, M., Baldus, S. 2011. Myeloperoxidase attracts neutrophils by physical forces. Blood 117, 13501358.

Livak, K.J., Schmittgen, T.D. 2001. Analysis of relative gene expression data using real-time quantitative $\mathrm{PCR}$ and the $2^{-\Delta \Delta \mathrm{C}}$ Method. Methods 25(4), 402408.

Mesbah, L., Soraya, B., Narimane, S., Jean, P.F. 2004. protective effect of flavonides against the toxicity of vinblastine cyclophosphamide and paracetamol by inhibition of lipid peroxydation and increase of liver glutathione. Haematol 7 (1), 59-67.

Moore, S.M., Kremer, M., Sanderlin, E.J., Wheeler, M.D., Hines, I.N. 2013. Emerging Roles for Lipids in the Hepatic Innate Immune Response. Hum. Nutr. Food. Sci 1, 1-9.

Moridani M., Pourahmad J., Bui H., Siraki A., O’Brien P. 2003. 'Dietary flavonoid iron complexes as cytoprotective superoxide radical scavengers', Free Radic. Biol. Med 34, 245-253.
Moridani, M.Y., Pourahmad, J., Bui, H., Siraki A., O’Brien, P.J. 2003. Dietary flavonoid iron complexes as cytoprotective superoxide radical scavengers. Free Radic. Biol. Med 34, 243-253.

Mossa, A.T.H., Swelam, E.S., Mohafrash, S.M.M. 2015. Sub-chronic exposure to fipronil induced oxidative stress, biochemical and histopathological changes in the liver and kidney of male albino rats. Toxicol Reports 2, 775-784.

Naik, S.R., Panda, V.S. 2008. Hepatoprotective effect of Ginkgoselect Phytosome in rifampicin induced liver injury in rats: evidence of antioxidant activity. Fitoterapia 79, 439-445.

Nakamoto, N., Kanai, T. 2014. Role of tolllike receptors in immune activation and tolerance in the liver. Front. Immunol; 5: 221-229.

Ojo, A.O., Oyinloye, B.E., Ajiboye, B.O., Ojo, A.B., Akintayo, C.O., Okezie, B. 2014. Dichlorvos induced nephrotoxicity in rat kidney: protective effects of Alstonia boonei stem bark extract. Indian J Pharmacol 1, 429-437.

Pattanasupong, A., Nagase, H., Sugimoto, E., Hori, Y., Hirata, K., Tani, K., Nasu, M., Miyamoto, K. 2004. Degradation of carbendazim and 2,4dichlorophenoxyacetic acid by immobilized consortium on loofa sponge. J Biosci Bioeng 98, 28-33.

Patterson, J.W., Lazarow, A. 1955. Determination of glutathione; Methods of Biochemical Analysis 2, 259-278.

Rice-Evans, C.A., Miller, N.J., Bolwell, P.G. 1995. The relative antioxidant 
activities of plant derived polyphenolic flavonoids. Free Radic Res 22, 375-383.

Sakr S.A., Abel-Samie, H.A.2008. Apoptosis related protein Bax in liver of metalaxyl fungicide -treated mice: The effect of antox. Ozean J Appl Science 1(1), 17-27.

Sakr, S.A. 2007. Ameliorative effect of ginger (Zingiber officinale) on mancozeb fungicide induced liver injury in albino rats. Australian J. Basic Appl. Sci 1(14), 650-656.

Sakr, S.A., Lamfon, H.A. 2005. Effect of green tea on metalaxyl fungicide induced liver injury in albino mice.Oxford Res.Forum J 2(2), 65-69.

Schultke, E., Griebel, R.W., Juurlink, B.H.J. 2010. Quercetin attenuates inflammatory processes after spinal cord injury in an animal model. Spinal Cord 48, 857-861.

Schumann, G., Bonora, R., Ceriotti, F., Férard, G., Ferrero, C.A., Franck, P.F., Gella, F.J., Hoelzel, W., Jørgensen, P.J., Kanno, T., Kessner, A., Klauke, R., Kristiansen, N., Lessinger, J.M., Linsinger, T.P., Misaki, H., Panteghini, M., Pauwels, J., Schiele, F., Schimmel, H.G., Weidemann, G., Siekmann, L. 2002. IFCC primary reference procedures for the measurement of catalytic activity concentrations of enzymes at 37 degrees C. International Federation of Clinical Chemistry and Laboratory Medicine. Part 6. Reference procedure for the measurement of catalytic concentration of gamma- glutamyltransferase. Clin Chem Lab Med 40(7), 734-738.

Sidhu, I.P.S., Bhatti, J.S., Bhatti, G.K. 2014. Modulatory action of melatonin against chlorpyrifos induced hepatotoxicity in Wistar rats. Asian J Med Sci 2, 123-131.

Sukul, P., Spiteller, M. 2000. Metalaxyl: persistence, degradation, metabolism, and analytical methods. Rev Environ Contam Toxicol 164, 1-26.

Suzuki, Y.J., Tsuchiya, M., Packer, L. 1991. Thioctic acid and dihydrolipoic acid are novel antioxidants which interact with reactive oxygen species. Free Radic Res Commun 15, 255-263.

Tinay, I., Sener, T.E., Cevik, O., Cadirci, S., Toklu, H., Cetinel, S., Sener, G., Tarcan, T. 2017. Antioxidant agent quercetin prevents impairment of bladder tissue contractility and apoptosis in a rat model of ischemia/reperfusion injury. Lower urinary tract symptoms 9: 117-123.

United States Environmental Protection Agency UEPA 1994. R.E.D. FACTS Metalaxyl. Prevention Pesticides And Toxic Substances $(7508 \mathrm{~W})$. EPA738-F-94-013.

Xu, J.B., Yuan, X.F., Lang, P.Z. 1997. Determination of catalase activity and catalase inhibition by ultraviolet spectrophtometry. Chinese Environ. Chem 16, 73-76.

Zoja, C., Benigni, A., Remuzzi, G. 2014. The Nrf2 pathway in the progression of renal disease. Nephrol. Dial. Transplant 29, 19-24. 